\title{
Sandstone geomorphology of the Golden Gate Highlands National Park, South Africa, in a global context
}

\author{
Authors: \\ Stefan W. Grab \\ Andrew S. Goudie ${ }^{1,2}$ \\ Heather A. Viles ${ }^{1,3}$ \\ Nicola Webb ${ }^{1}$ \\ Affiliations: \\ ${ }^{1}$ School of Geography, \\ Archaeology and \\ Environmental Studies, \\ University of the \\ Witwatersrand \\ South Africa \\ ${ }^{2}$ St Cross College, \\ University of Oxford, \\ United Kingdom \\ ${ }^{3}$ School of Geography \\ and the Environment, \\ University of Oxford, \\ United Kingdom \\ Correspondence to: \\ Stefan Grab \\ Email: \\ stefan.grab@wits.ac.za \\ Postal address: \\ Private bag $\times 3$, \\ Witwatersrand University \\ 2050, South Africa \\ Dates: \\ Received: 04 Jan. 2010 \\ Accepted: 12 Nov. 2010 \\ Published: 14 Mar. 2011 \\ How to cite this article: \\ Grab, S.W., Goudie, A.S., \\ Viles, H.A. \& Webb, \\ N., 2011, 'Sandstone \\ geomorphology of the \\ Golden Gate Highlands \\ National Park, South Africa, \\ in a global context', Koedoe \\ 53(1), Art. \#985, 14 pages. \\ doi:10.4102/koedoe. \\ v53i1.985
}

(C) 2011. The Authors.

Licensee: OpenJournals Publishing. This work

is licensed under the

Creative Commons

Attribution License.
The Golden Gate Highlands National Park (GGHNP) is well known for its impressive sandstone formations. While previous geoscience research in the park has focused on geology, palaeontology, slope forms and the prominent lichen weathering, remarkably little has been written on the diversity and possible origins of sandstone phenomena in the region. The objectives of this study were (1) to present a geomorphological map of prominent and interesting landforms for particular portions of the park and (2) to document the variety of macro- and microscale sandstone formations observed. During field work, we undertook global positioning system measurements to map landforms and, in addition, measured the dimensions of several landform types. A Schmidt hammer was used to conduct rock hardness tests at a variety of localities and lithologies for comparative purposes. We indentified and mapped 27 macro- and microscale sandstone landforms, of which 17 are described in detail. It is demonstrated that for the most part, the landforms are a likely product of surface lithological reactions to a regional climate characterised by pronounced multitemporal temperature and moisture shifts, recently and in the past. However, many of the geomorphological processes producing landforms are controlled by microclimates set up by factors such as macro- and microtopography.

Conservation implications: The GGHNP is best known for its geological, geomorphological and palaeontological heritage. This paper highlights the diversity of sandstone geomorphological phenomena, many of them rare and 'unique' to the region. Not only are these landforms of aesthetic interest to tourists, but they also provide microhabitats for biota. Thus, conservation of biota requires associated conservation of geo-environments where they are established.

\section{Introduction}

The work Sandstone landforms (Young, Wray \& Young 2009) provides a global view of our current understanding of macro- and microscale sandstone landforms and their associated geomorphic processes. It provides numerous examples of sandstone landforms from around the world and highlights the many important new studies that have appeared from South America, Australia, central Europe and China, in particular. Although the book identifies the Clarens area of the northeastern Free State as one of the world's 61 major sandstone landscapes, relatively little is known about the diversity of sandstone phenomena and their process origins in southern Africa. Despite sandstones not generally being as well known for their distinctive landforms as are limestones and granites (Robinson \& Williams 1994), the Golden Gate Highlands National Park (GGHNP) hosts some of southern Africa's most spectacular scenery. The GGHNP has been identified as a geotourism hotspot, with the defining feature being the 'red, cream and yellow weathered sandstone of the Clarens Formation that is deeply eroded to form bluffs and cliffs' (Reimold, Whitfield \& Wallmach 2005:55). In recent years several World Heritage sites have been proclaimed in South Africa, and more than half of those currently listed and proposed represent entirely natural geological heritage (Reimold et al. 2005). The GGHNP falls within the Drakensberg World Heritage region, which boasts mixed heritage status owing to the presence of both culturally and naturally significant features. It is thus not surprising that the GGHNP has become a world-famous geotourism destination, with particular attractions including the Brandwag 'Golden Gate' (Figure 1), San rock art and vertebrate fossils.

The GGHNP was established in 1963 for the purpose of protecting a pristine area, but more specifically, to conserve the impressive sandstone formations (hence its name) and the montane and Afro-Alpine grassland biome (SANParks 2004). Previous earth science research in the park has focused mainly on the geological and palaeontological heritage and macroscale geomorphological evolution (e.g. Groenewald 1986; Kitching \& Raath 1984; Spies 1969), slope forms and processes 


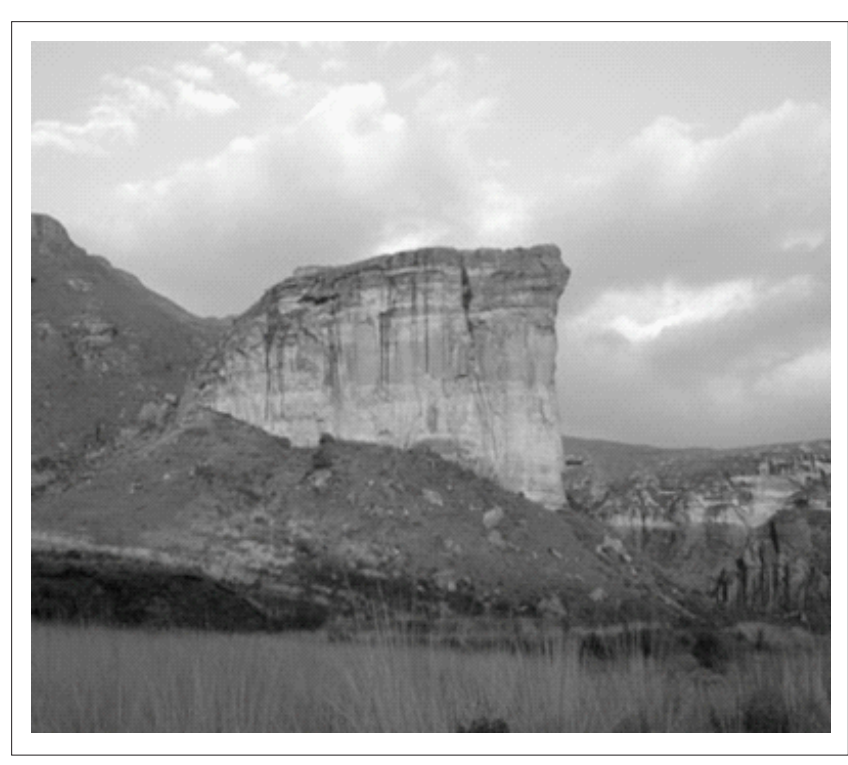

FIGURE 1: The Brandwag 'Golden Gate', displaying Clarens Formation sandstone cliffs.

(Moon 1991; Moon \& Munro-Perry 1988; Nicol 1973), biogenic weathering (Büdel et al. 2004; Wessels \& Büdel 1995; Wessels \& Schoeman 1988; Wessels \& Wessels 1991, 1995; Wessels et al. 1995), weathering basins (Cooks \& Pretorius 1987) and the origins of 'cave' formations (Le Roux 1978). Despite these previous studies and the recognition of the regional geoheritage, the diversity of both macro- and microscale sandstone landforms has not yet been comprehensively documented or mapped in the GGHNP. To this end, our objective was, firstly, to provide a map of prominent and interesting sandstone phenomena for particular portions of the park, thus contributing to enhanced knowledge on geodiversity. Secondly, we aimed to document the variety of macro- and microscale sandstone morphologies (Table 1) and their possible process origins within a global context. Although we concentrate here on sandstone features, some of our observations may also be relevant to granitic terrains, which often have similar assemblages of weathering forms (see Twidale \& Vidal Romaní 2005).

\section{Study area}

The GGHNP is located in the eastern Free State $\left(28^{\circ} 31^{\prime} \mathrm{S}\right.$, $28^{\circ} 37^{\prime} \mathrm{E}$ ) and covers an area of $120 \mathrm{~km}^{2}$ across the Rooiberg Mountain Range (1892-2837 m a.s.l.), which forms part of the greater Drakensberg-Maluti mountain system (Figure 2). Although annual precipitation varies considerably across the region, it averages approximately $764 \mathrm{~mm}$, of which most falls between November and April (Groenewald 1986). Summers are mild to warm (mean temperature ranges from $13^{\circ} \mathrm{C}$ to $26^{\circ} \mathrm{C}$ ) and winters cold (mean temperature ranges from $1{ }^{\circ} \mathrm{C}$ to $\left.15^{\circ} \mathrm{C}\right)$. (Cooks \& Pretorius 1987). Frost is widespread during the winter months and snow occasionally falls on the higher peaks in the park. The vegetation is typically Highlands Sourveld and Themeda-Festuca Alpine Veld, with identified plant communities representative of the Tristachya leucothrixTrachypogon spicatus Grassland of moist mountain slopes and plateaus, and to some extent the Merxmuellera drakensbergensis - Festuca caprina high-altitude Austro-Afro Alpine Grassland
(Du Preez \& Bredenkamp 1991; Kay, Bredenkamp \& Theron 1993). The area is located on the African Surface of Partridge and Maud (1987) and its drainage systems have undergone subsequent incision (Moon \& Munro-Perry 1988). The observed landscape has been influenced by ever-changing climates, particularly during the Quaternary period, which encountered an intensification of cold climate processes and also major changes in vegetation cover (Henderson et al. 2006). The landforms of the area thus have a long and complex geomorphic history.

\section{Methodology}

Large portions of the sandstone sections of the GGHNP were traversed, with sandstone phenomena photographed and recorded using a global positioning system device. The recorded phenomena could then be incorporated onto existing topographic and geological maps. For some landforms and topographic settings we undertook morphometric and rock hardness measurements using a tape measure and a Schmidt hammer (classic N-type), respectively. The Schmidt hammer indicates rebound values ( $R$-values ranging from 0 to 100), which are proportional to the hardness of the rock. Rock hardness as described here is based on the indentation produced when pressure is exerted on the rock mass (as opposed to individual mineral hardness, which indicates resistance to scratching). Rock surfaces were first cleaned (smoothed) using a Carborundum, after which the hammer was applied to the smoothed surface. Mean rebound values were calculated from $30-50$ readings per site. The objective with this was primarily to compare the hardness of Clarens Formation sandstone with that of other geological units in the park and consequently its potential strength variability in various spatial and geological contexts.

Young et al. (2009) classify sandstone phenomena into four hierarchical groupings, based on morphology rather than process origins. We classify the sandstone landforms observed in the GGHNP according to size and morphological attributes. However, given that microsurface forms such as case hardening and spalling (flaking) contribute to the development of other sandstone features (e.g. rock basins and tafoni), these are dealt with first as part of the geological structure which invariably impacts on landform genesis.

While a variety of landform types are discussed within separate subsections for ease of presentation, it should be acknowledged that several varieties of sandstone phenomena may be closely linked and have common developmental origins despite their different morphological surface expressions. Such differences may be due to macro- and microtopographic position, existing surface morphology and differences in underlying geological controls. For instance, rock doughnuts, rock basins and rock pans within a region may have common process geomorphic origins but the outcomes may spatially take on rather different visible forms.

\section{Geological context}

The sedimentary portion of the Late Carboniferous - Middle Jurassic Karoo Basin of southern Africa includes glacial 


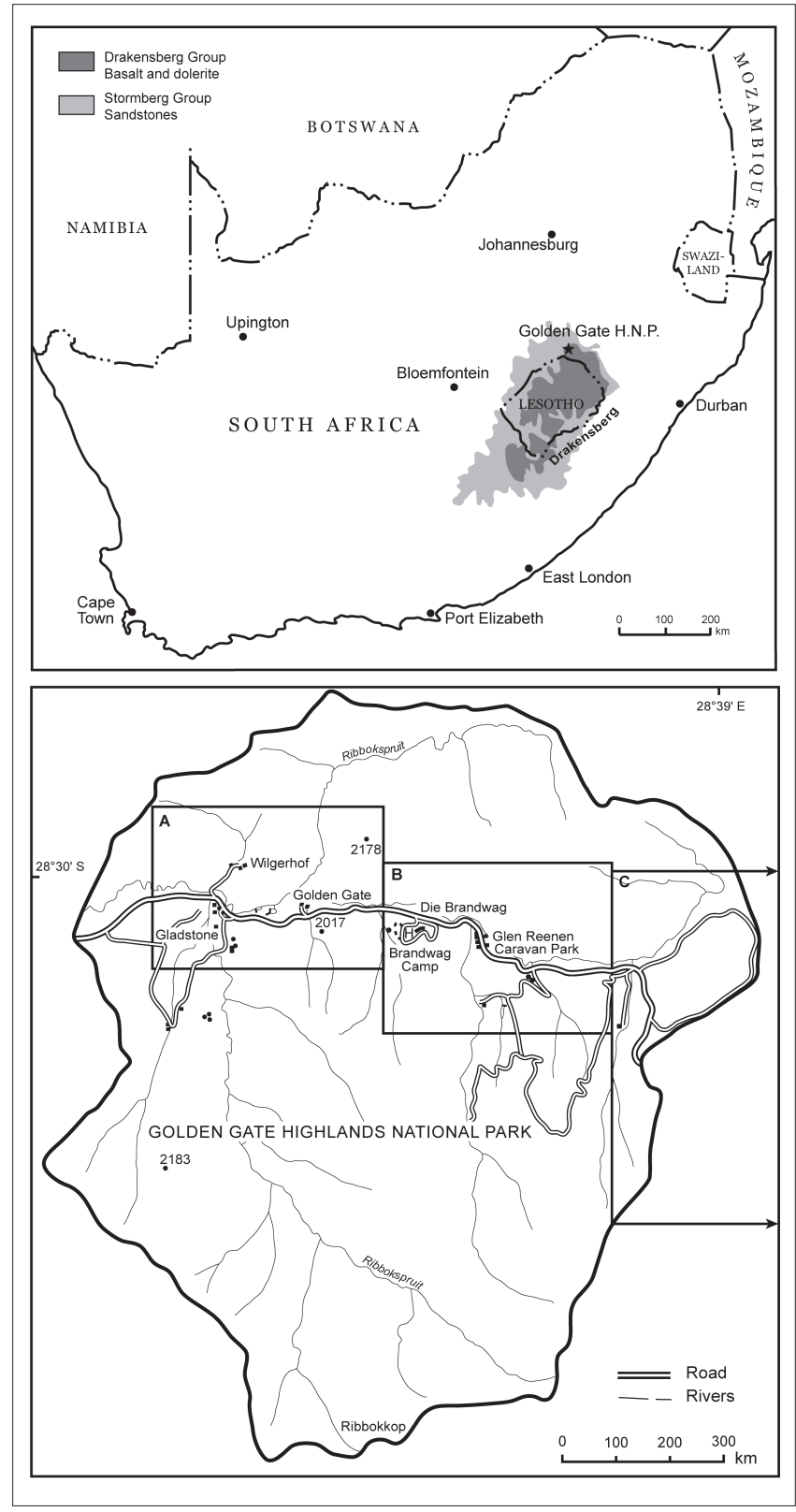

FIGURE 2: Location of the Golden Gate Highlands National Park and map of the park showing the insets for the geomorphological maps in Figure 3.

(Dwyka Group), marine, swamp and deltaic (Ecca Group), fluvial (Beaufort Group and parts of the Stormberg Group) and aeolian (upper part of the Stormberg Group) deposits, and is capped by the volcanic Drakensberg Group (Catuneanu, Hancox \& Rubidge 1998; Catuneanu et al. 2002; Smith et al. 1998). Sills and dykes were emplaced in sedimentary strata around $183 \mathrm{Ma}$ (Holzförster 2007) and in places may form up to $70 \%$ of the basin volume (Rowsell \& De Swardt 1976; Svensen et al. 2006). The Stormberg Group is made up of the Molteno, Elliot and Clarens Formations, all of which are represented in the GGHNP (Eriksson 1981, 1984, 1985; Groenewald 1986). While the Elliot Formation has a distinct lower contact with the Molteno Formation, it has a more gradual upper contact with the Clarens Formation (Bordy, Hancox \& Rubidge 2004; Groenewald 1986). The succession reflects changing palaeo-environmental conditions (climatic and basin foreland tectonics) during deposition; from dominantly fluvial (Molteno Formation) to increasingly aeolian (Clarens Formation) (Bordy et al. 2004; Eriksson 1981, 1984, 1985; Groenewald 1986).

Sandstones are produced through the cementation or lithification of sand grains through processes of pressure melting and recrystallisation, compaction and consolidation of incorporated clay minerals, and/or by the precipitation of authigenic minerals from water migration through pores (Robinson \& Williams 1994). Although a wide variety of sandstones occur in the GGHNP, primarily owing to a diversity of depositional mechanisms, they are, for the most part, a product of compaction and consolidation over time. The Molteno Formation varies in thickness from less than $10 \mathrm{~m}$ to more than $100 \mathrm{~m}$ and consists of light-coloured sandstones of which the grains can range from fine to very coarse (Eriksson 1984). The Molteno Formation sandstones are primarily quartz-rich feldspathic wackes, have a high interstitial content and sometimes tend towards subordinate argillaceous and conglomeritic structures (Eriksson 1984). The Elliot Formation varies in thickness from approximately $28 \mathrm{~m}$ to more than $150 \mathrm{~m}$ and consists of red-coloured, argillaceous sandstone with grains ranging from fine to coarse (Eriksson 1985). The Elliot Formation is particularly well known in the GGHNP for its vertebrate fossil content (e.g. Groenewald 1986; Kitching \& Raath 1984). The Clarens Formation is typically $115 \mathrm{~m}-195 \mathrm{~m}$ thick and consists of light-coloured, fine-grained sandstones, sandy siltstones and mudstones, and subordinate coarser-grained components (Eriksson 1981). Fresh faces of the rock collected from boreholes and quarries are white, yet on exposure the rock weathers to give its characteristic tan or golden colour. However, there have been no detailed studies on the chemical and mechanical weathering processes causing such colour alterations. The sedimentary strata, which are generally approximately horizontally bedded, have been intruded by several fine- to coarse-grained dolerite dykes and a few sills in the GGHNP (Groenewald 1986). Some major faults occur in association with these intrusions and these are likely to have played a role in the genesis of the landforms, as has the presence of the bedding planes and joints within the sedimentary rocks.

Schmidt hammer testing of the rocks in the area provides estimates of the hardness characteristics of the various rock units (Table 2). The mean Schmidt hammer hardness $R$-value for the Clarens Formation sandstone, based on 30-50 readings from each of nine sites, was 48.91 . This is marginally higher than the $R$-values that have been recorded at two other major sandstone geomorphological sites: approximately 45 for the Navajo sandstone of Utah (Irwin et al. 2009) and 41-44.7 for the Cambrian-Ordovician sandstones of Wadi Rum in Jordan (Goudie et al. 2002). The $R$-value for a dolerite dyke piercing the Clarens Formation sandstone was 63.0, while that for Drakensberg Group basalt was 55.92. Sandstone of the Elliot Formation had an $R$-value of 58.12. Thus, all the main rock units in the area are relatively hard. However, the wide variety of rock hardness values (compressive strength) obtained across sandstone surfaces in the GGHNP attests to both macro- and microscale variability in porosity, 
TABLE 1: A scale hierarchy of sandstone landforms in the Golden Gate Highlands National Park.

\begin{tabular}{|c|c|c|}
\hline Large $(>100 \mathrm{~m})$ & Medium $(10 m-100 m)$ & Small (< $1 \mathrm{~m})$ \\
\hline - Cliffs & $\begin{array}{l}\text { - Pillars } \\
\text { - Buttresses } \\
\text { - Arches } \\
\text { - Rock shelters } \\
\text { - Alcoves } \\
\text { - Caves } \\
\text { - Tafoni }\end{array}$ & - Honeycombs \\
\hline - Interfluves Plateaus & $\begin{array}{l}\text { - Pedestal rocks } \\
\text { - Rock basins } \\
\text { - Rock doughnuts }\end{array}$ & $\begin{array}{l}\text { - Tessellations } \\
\text { - Polygonal boxwork } \\
\text { - Fluting } \\
\text { - Gutters } \\
\text { - Trittkarren } \\
\text { - Lichen pits }\end{array}$ \\
\hline $\begin{array}{l}\text { - Low-angle convex valley side } \\
\text { slopes }\end{array}$ & $\begin{array}{l}\text { - Turf slides } \\
\text { - Boulder fields }\end{array}$ & $\begin{array}{l}\text { - Tessellations } \\
\text { - Polygonal boxwork } \\
\text { - Fluting } \\
\text { - Gutters } \\
\text { - Trittkarren } \\
\text { - Lichen pits }\end{array}$ \\
\hline
\end{tabular}

composition and bonding of mineral grains, and the extent of surface weathering or case hardening. Although not yet locally tested, it is thus likely that many of the sandstone morphologies at the GGHNP are a product of differential rates and processes of weathering and erosion across microscales, owing at least in part to rock hardness variability.

\section{'Blueberries' (concretions)}

Calcareous and ferruginous concretions are particularly common to the sandstones of the Clarens Formation (Groenewald 1986), where they impact on the fine-scale spatial dynamics of weathering processes. Such concretions are sometimes informally referred to as 'blueberries', possibly owing to their nodular spheroidal structure (Squyres \& Knoll 2005). According to Mahaney et al. (2008), it is thought that such surface nodules are the product of subsurface fluid migration through porous sandstone. Fluids become enriched with iron and calcite, with precipitates eventually forming around a central nucleus of fine sandstone particles (Mahaney et al. 2008). These are released when the host sandstone is weathered and produce a surface lag.

\section{Case hardening}

An important and common attribute of many sandstone surfaces is the development of a surface crust or 'outer [shell] more resistant to erosion than interior material' (Dorn
2004:118). Crust development is primarily caused by the deposition of solutes when pore water migrates towards the surface and evaporates (Robinson \& Williams 1994). However, the processes causing case hardening may be polygenetic in origin and vary between sites. For example, it has been found that micro-organic biofilms may aid the cementation process to produce case-hardened surfaces in Jordanian sandstones (Viles \& Goudie 2004). Examples of case hardening occur throughout the GGHNP where the iron-rich crusts produce hardened, reddish surfaces. The importance of case hardening cannot be underestimated: on the one hand, it protects underlying rock from weathering and, on the other, it reduces localised infiltration and so facilitates enhanced surface runoff. Both these functions consequently impact on weathering and erosion on the surrounding uncrusted rock surfaces. In addition, the disintegration of the surface crust provides new irregularities that may promote localised weathering and erosion and consequently lead to new phenomena such as rock basins (weathering pits) (Goudie \& Migón 1997).

\section{Surface spalling (exfoliation, flaking)}

In arid and semi-arid regions (or microsettings) with seasonal rainfall (humidity) patterns, sandstone may be susceptible to spalling or flaking (i.e. thin rock flakes peeling off). In such instances cracks develop parallel to the surface, typically at a depth of between $5 \mathrm{~mm}$ and $50 \mathrm{~mm}$ (Robinson \& Williams 1987, 1992). Spalling of rock surfaces is common where cracks develop below a case-hardened surface, or along the backwalls of tafoni caverns and rock shelters. It is understood that a primary mechanism for such sandstone spalling is the dissolution of silica and other cementing agents during wetting cycles and the translocation in the surface layers during drying cycles (Robinson \& Williams 1992). Crystallisation of salt during desiccation cycles has also been observed to cause spalling (Goudie \& Viles 1997; Holmer 1998). Observations on the backwalls of cavernous weathering features show that in the GGHNP there are salt efflorescences associated with spalling rock. It has also been suggested that contemporary sub-zero air temperatures at the GGHNP during the winter period may contribute to frost action (spalling) where moisture is locally available (Marker 1990); however, freeze-thaw processes are considered contentious given that rock thermal data required to prove such a mechanism have not been forthcoming (Hall, Marker \& Le Roux 1991).

TABLE 2: Hardness values as measured with a Schmidt hammer (classic N) for rock types in the Golden Gate Highlands National Park.

\begin{tabular}{|c|c|c|c|}
\hline Rock type & Site characteristics & Mean $R$-value (corrected) & Sample size \\
\hline Clarens sandstone & Horizontal open surface & 57.90 & 50 \\
\hline Clarens sandstone & Horizontal surface of boulder & 52.71 & 30 \\
\hline Clarens sandstone & Horizontal surface of boulder & 47.96 & 30 \\
\hline Clarens sandstone & Horizontal open, dry surface & 51.15 & 50 \\
\hline Clarens sandstone & Horizontal open surface after wetting & 49.95 & 50 \\
\hline Clarens sandstone (case hardened) & Rock shelter caprock vertical face & 45.32 & 50 \\
\hline Clarens sandstone (weathered) & Vertical backwall of rock shelter & 46.78 & 50 \\
\hline Clarens sandstone (iron crusted) & Horizontal open surface & 45.02 & 50 \\
\hline Clarens sandstone (baked) & Vertical surface on ridge adjacent to dolerite dyke & 43.42 & 50 \\
\hline Dolerite & Vertical face of dolerite dyke & 63.20 & 50 \\
\hline Basalt & Vertical face of basalt outcrop & 55.92 & 50 \\
\hline Elliot sandstone & Vertical face & 58.12 & 50 \\
\hline
\end{tabular}




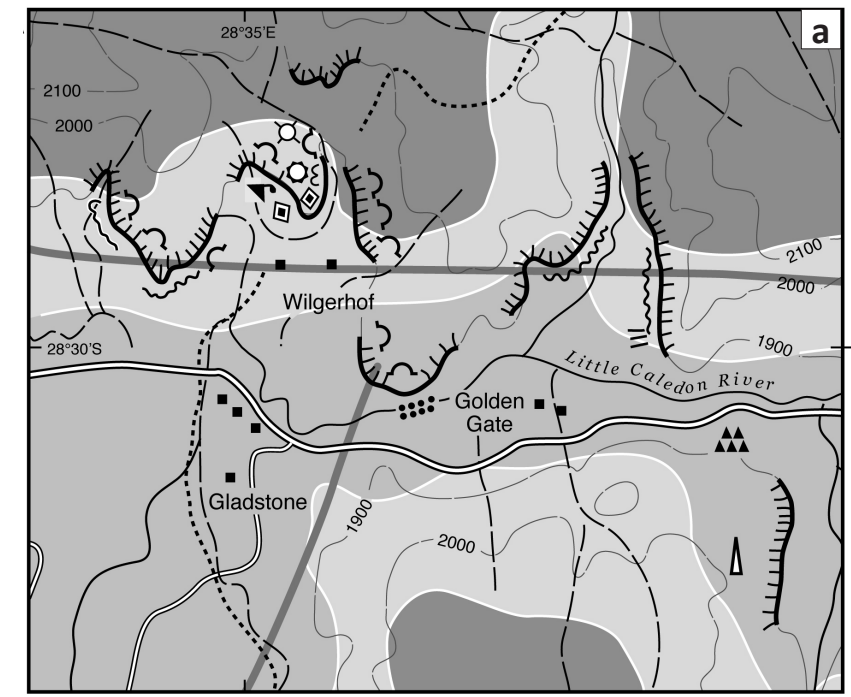

Geomorphological legend

\begin{tabular}{|c|c|c|c|c|c|}
\hline 〈w & Cliffs & 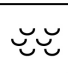 & $\begin{array}{l}\text { Slopes with } \\
\text { terraces }\end{array}$ & $\varepsilon$ & Fluting \\
\hline & Flared slope & & Overhangs & $=$ & Indurated joints \\
\hline & $\begin{array}{l}\text { Buttress } \\
\text { Boulder tongue }\end{array}$ & & $\begin{array}{l}\text { Hollows/rock } \\
\text { shelters/ } \\
\text { caverns }\end{array}$ & a & $\begin{array}{l}\text { Prominent lichen } \\
\text { weathering } \\
\text { Undercutting }\end{array}$ \\
\hline : & Dome & & Arch & $\|$ & $\begin{array}{l}\text { Bedrock channels } \\
\text { and Karren forms }\end{array}$ \\
\hline 录 & Basal concavities & & Bute & $\infty$ & Polygonal cracking \\
\hline Au & Balancing rocks & 0 & $\begin{array}{l}\text { Rock basins } \\
\text { Rock doughnuts }\end{array}$ & $\eta$ & $\begin{array}{l}\text { Solutional } \\
\text { notches }\end{array}$ \\
\hline :::• & Block field & 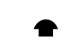 & Pedestal rock & * & Flaking \\
\hline
\end{tabular}
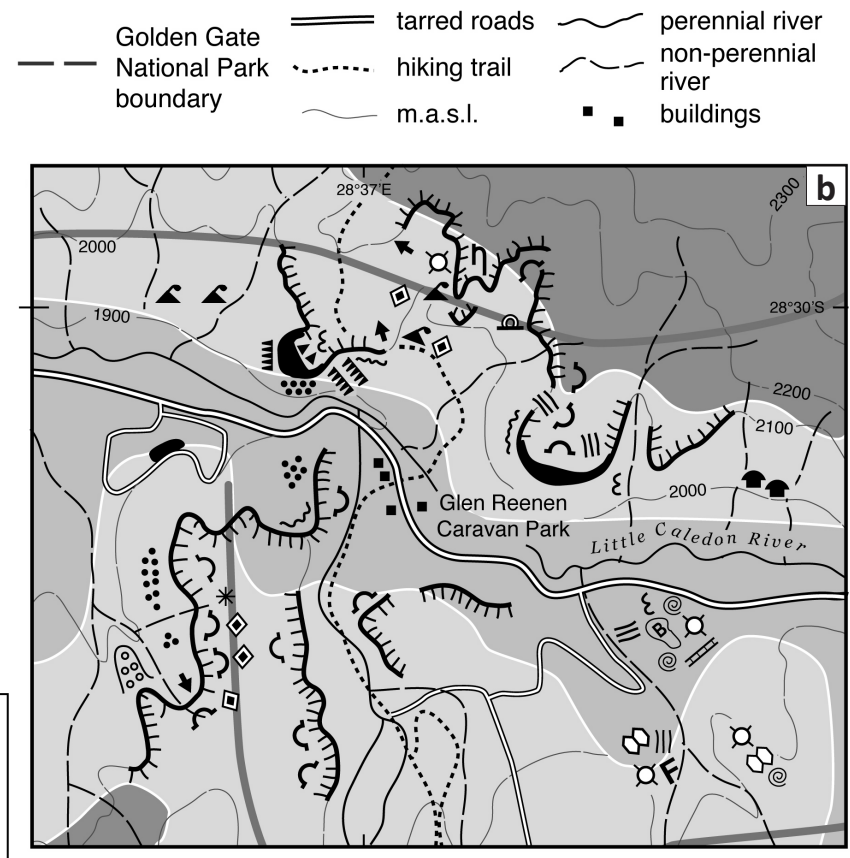

$\triangle$ Pillar

$\diamond$ Honeycombs and

tafoni

P Plateau-like

P structures

F Fossil remains

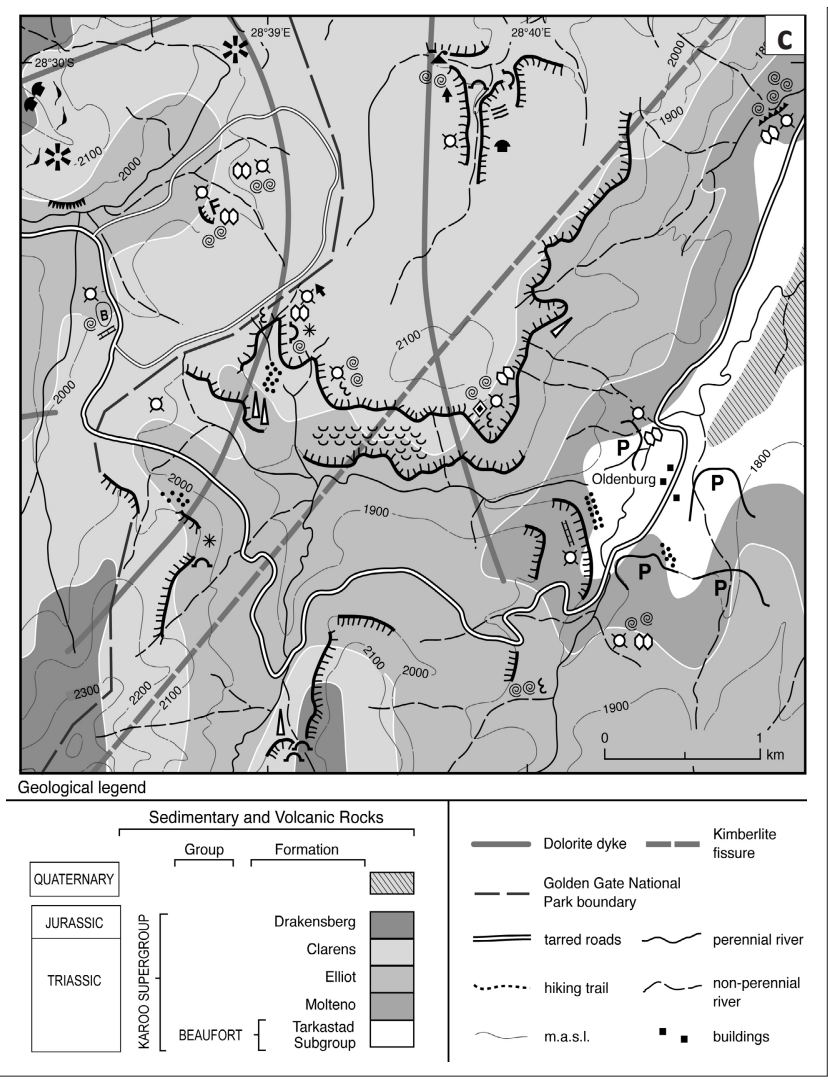

FIGURE 3: Geomorphological map of sandstone phenomena in the Golden Gate Highlands National Park (geological overlays modified after Geological Series 2828 Harrismith, Council for Geoscience, 1998; localities of subfigures a-c as shown in Figure 2).
A further mechanism causing widely distributed spalling on rock surfaces in the GGHNP is substrate alkalisation during the photosynthesis of cryptoendolithic cyanobacteria (Büdel et al. 2004). This process is particularly prominent on the surfaces of Clarens Formation sandstones. Biofilms dominated by cryptoendolithic cyanobacteria are common here and the in situ $\mathrm{pH}$ values of the sandstone typically range between 9.5 and 10.5 along endolithic growth zones, which enhance dissolution of $\mathrm{SiO}_{2}$ (Büdel et al. 2004).

\section{Sandstone geomorphological map of the GGHNP}

We have mapped both macro- and microscale sandstone phenomena on a common base map to indicate prominent and/or unique features that may be of particular interest to geotourists (Figure 3). While the resolution does not permit detailed information at the metre scale or the mapping of all phenomena, it does allow for the identification of prominent or abundant forms within particular areas of the GGHNP, which can guide visitors in making associations between local relief and/or geology.

Figure 3 provides a legend of the mapped sandstone phenomena in the GGHNP, most of which are discussed in detail later. General observations suggest that although most macro- and microscale sandstone phenomena occur widely within the various sedimentary formations of the Karoo Supergroup, the uppermost broad sandstone plateaus of the Clarens Formation host the highest density and greatest 
variety of sandstone landforms. Notably, such plateaus are topographic positions capable of storing considerable quantities of surface water during the wet season (particularly where infiltration is relatively low or drainage is poor), while also being subjected to substantial heating and cooling cycles because of exposure. To this end, Paradise (2002) found that aspect-controlled weathering processes and associated landform production are particularly pronounced in regions where wetting-drying and heating-cooling cycles are important weathering mechanisms, such as have been observed in Petra, Jordan. Dolerite dyke intrusions are also likely to have influenced landform development within the adjacent sandstones in the GGHNP, and we note phenomena such as flared slopes, a rock arch, caverns, honeycombs and rock basins adjacent to some of the dykes.

\section{Slope forms}

1. General slope forms and processes: As a consequence of fluvial incision by the Little Caledon and its tributaries, the GGHNP has a variety of slope forms, ranging from horizontal sandstone pavements along broad interfluves to vertical cliffs along valley margins. The variable nature of bedrock forms (gradients) has to a large extent controlled the development of microscale sandstone phenomena through controlling the amount of solar radiation received at the rock surface (rock surface microclimatology), moisture retention, surface water movement and gravity. There is likely feedback as the microscale phenomena contribute to the further evolution of the larger slope forms.

The prominent slope forms in the GGHNP are rectilinear cliff-talus slope combinations and bedrock slopes inclined at $30^{\circ}-35^{\circ}$ (Moon \& Munro-Perry 1988). The presence of a resistant and relatively massive caprock (normally Clarens Formation sandstone) permits parallel slope retreat and the preservation of rectilinear slopes where the rock mass strength values are higher than 70 . However, where values are lower, the rock is too weak to preserve the Richter slope forms and thus undergoes a process of 'slope replacement' (Moon 1991; Moon \& Munro-Perry 1988). Most valley sides typically have near-vertical cliffs and/or steeply inclined $\left(>35^{\circ}\right)$ bedrock surfaces, below which is a zone of discontinuous debris cover ('vegetated islands') on somewhat gentler slopes $\left(20^{\circ}-35^{\circ}\right)$. These 'vegetated islands' (Figure 4a) appear to be the result of peat rafts' sliding over the underlying bedrock, although there is evidence that the movements are complex and involve diffusive, waterborne erosion of sediment as well as sliding. Finally, there is a zone of debris accumulation on lower slope units approaching the valley floor (Moon \&
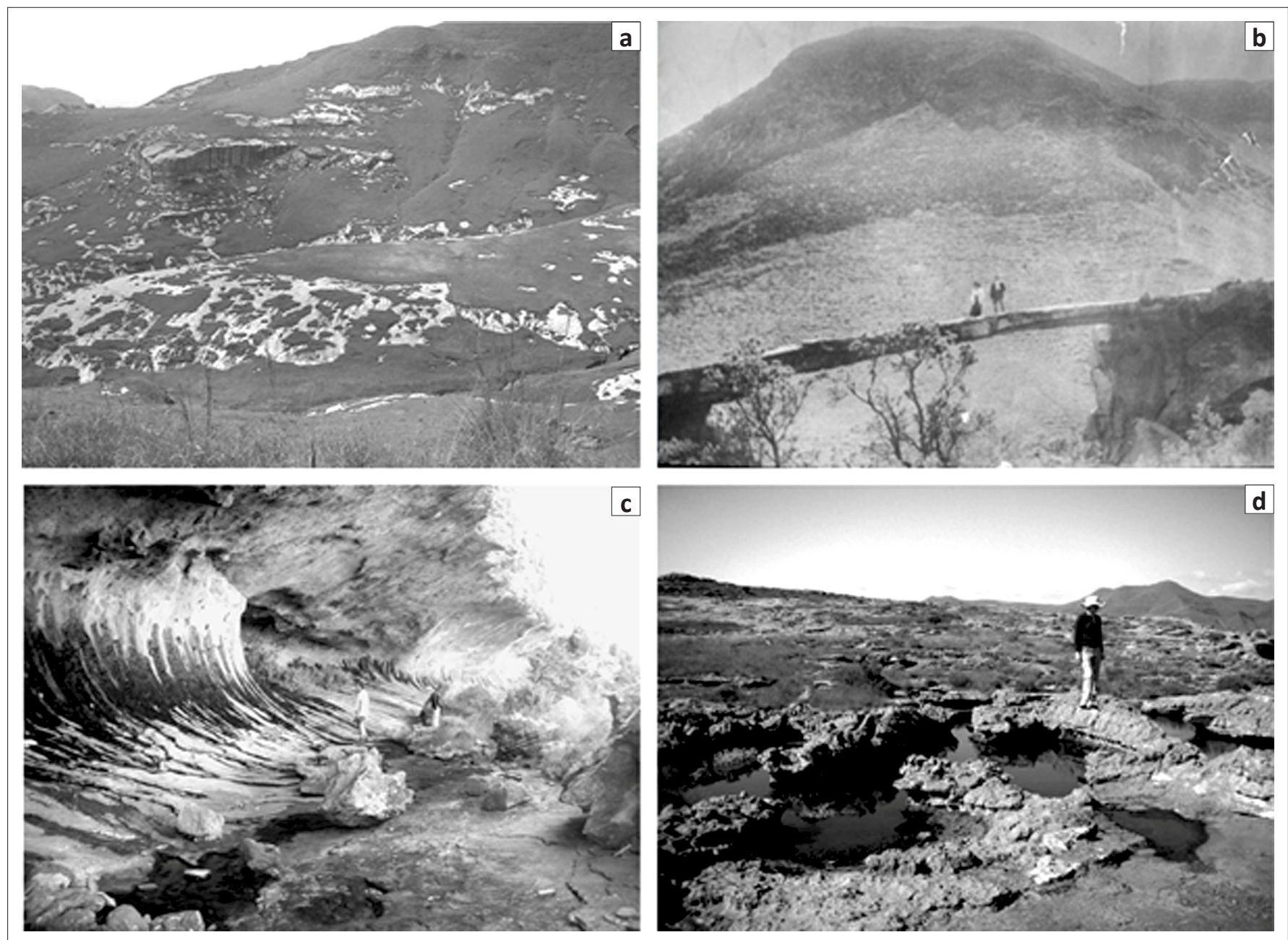

FIGURE 4: (a) 'Vegetated islands' overlying sandstone outcrops, (b) a natural stone bridge spanning the Zulu Hoek stream (since collapsed; electronic copy of original photo provided by Johan Taljaard, GGHNP), (c) water seepage and associated black staining at the rear of a cavern and (d) large rock basins with distinct water level notches. 
Munro-Perry 1988; Nicol 1973). The number and size of some of the blocks on slopes below the cliffs is impressive and shows the importance of rock falls from the cliffs above.

Prominent 'cirque-shaped' hollows frequent several of the south-facing slopes in the GGHNP and these were initially thought to have originated from nival and frostrelated processes during past Pleistocene cold phases, as were rockfall debris and thick colluvial mantles along the valley margins (Marker 1989; Nicol 1973). However, such cold-process origins were subsequently contested (Le Roux \& Marker 1990) and have not been given much further consideration.

2. Cliffs and pillars: Cliffs and pillars represent steep bedrock exposures, especially along deeply incised valleys or around the periphery of plateaus (Robinson \& Williams 1994). The conspicuous cliffs of the GGHNP are most prominent along the Caledon Valley and are primarily associated with the massive and strongly cemented fine-grained Clarens Formation sandstones. Although cliffs are also typical of the Molteno and Elliot Formations, the generally thicker and more stable Clarens Formation displays the most impressive and extensive cliff development in the region. The height of the cliffs, which in places exceed $100 \mathrm{~m}$ to make the cliffs among the highest in the world (Moon \& Munro-Perry 1988), is to some extent controlled by the thickness of the sandstone formations (i.e. sedimentary beds) and the associated extent of basal weathering and erosion.

The best-known cliff in the GGHNP is the 'Brandwag buttress' (Figure 1), alongside which the Clarens Formation sandstone has been intruded by a dolerite dyke, and consequently has yielded a hard quartzitic sandstone with greater resistance to weathering (Groenewald 1986). The recent collapse (i.e. during the last few hundred years) of joint-bounded blocks at a few localities also provides evidence that cliff development is an ongoing, contemporary process in the GGHNP. The formation of pillars is limited in the GGHNP as joints are relatively widely spaced and the sandstone structures are massive and coherent. Nevertheless, block structures along cliffs have developed in places owing to accelerated weathering and erosion along more closely spaced joints. Another feature of the valley side slopes is the local development of summit and buttress tors.

\section{Arches (natural stone bridges)}

Despite their unusual and aesthetic appeal, natural arches and bridges are among the least studied of sandstone landforms worldwide. Fairbridge (1968) classified features into 'arches' (which do not span a stream channel) and 'bridges' (which span a stream channel). A photograph (Figure 4b) and painting by Johan van Reenen, dating back to between 1930 and 1940, depict the former occurrence of a natural stone bridge spanning the Zulu Hoek stream in the park. Although few known natural stone bridges exist in the region today, some small natural arches presently occur in the park and the surrounding area. Elsewhere, such arches are said to be the product of enhanced weathering and water infiltration along parallel joints on cliff faces, eventually leading to material collapse and production of the 'window area' (Leasure, Kind \& Busby 2007).

\section{Pedestal rocks (mushroom-shaped pillars)}

Relatively little research has focused on sandstone rock pedestals and mushroom-shaped pillars, also described elsewhere as rock columns and bulbous pinnacles (Mueller \& Twidale 2002). Nevertheless, it is understood that such forms are the likely result of differential rates of weathering, which are enhanced along existing fracture-defined blocks and sheets in bedrock. Pedestals occasionally occur on slopes in the GGHNP; these were most likely initiated beneath a former mantle of regolith, which has subsequently been eroded and left behind such bedrock landforms of etch origin, as suggested by Mueller and Twidale (2002) for similar landforms identified in New Mexico, USA. Pedestals often have a characteristic basal concavity, above which are broader bedrock cappings, resembling a mushroom (Twidale \& Campbell 1992). Although such bedrock forms may have been initiated through original subsurface etching processes, once they have been exhumed, differential rates of weathering and erosion would have continued along existing joints and areas of locally weaker rock strength, particularly from induced fracturing (Ollier 1978). The formation of these forms may also have been controlled by spatial dynamics such as distance from the ground surface and aspect.

\section{Cavernous weathering}

Cavernous weathering has been described as 'differential weathering of a rock surface' which represents 'areas of material loss surrounded by intervening areas of stable rock surface (with minimal material loss)' (Turkington \& Phillips 2004:665). International research on cavernous weathering has focused on both microcavernous forms (e.g. negative spheroidal weathering forms [Wagner 1913], dewholes [Demek 1964] and honeycombs [e.g. McBride \& Picard 2004; Rodriguez-Navarro, Doehne \& Sebastian 1999]), and macrocavernous forms such as tafoni (e.g. Martini 1978; Matsukura \& Tanaka 2000; Mottershead \& Pye 1994), alcoves (Lamb et al. 2006) and rock overhangs (locally also known as rock shelters or caves). To this end, there has been limited discussion concerning the likely successive evolution of forms from honeycombs (embryonic tafoni) to tafoni to so-called rock shelters ('mature tafoni' or 'tafoni caverns'as described by Mellor, Short \& Kirkby 1997). Cavernous weathering is particularly prominent in crystalline rocks with a medium to coarse grain structure, including granites and sandstones (Jennings 1968; Mellor et al. 1997), and is thus active within the sandstones of the GGHNP.

1. Honeycombs: Honeycombs are the smallest of the cavernous weathering types (only few tens of centimetres across), consisting of closely spaced pits which are bounded by thin raised lips or walls (McBride \& Picard 2004). Such weathering of microforms have previously been described as stone lattices, stone lace or fretting (Mustoe 1982), but are more commonly also known as alveoli (e.g. Benito, Machado \& Sancho 1993; Grisez 1960). In some instances honeycombs may develop within larger cavernous forms such as tafoni, 
but are said to be affected more strongly by lithological heterogeneities (Martini 1978). In fact, Groenewald (1986) observed honeycombs in the GGHNP and similarly ascribed their formation to differential weathering associated with calcareous concretions. International research suggests that honeycombs are typically a product of solutional processes and the crystallisation of salt in the pits (e.g. Lambert 1980; McBride \& Picard 2004; Young 1987), while case hardening by iron oxide or calcium carbonate offers greater resistance to weathering along the surrounding, less denuded walls (Campbell 1999; McBride \& Picard 2004). The spatial occurrence of honeycombs in the GGHNP is likely controlled by local sandstone permeability, the extent of sandstone cementation and mineralogy.

2. Tafoni, caverns, alcoves (rock shelters, caves): Tafoni are relatively large (several metres across) cavernous weathering forms with overhanging hoods, arch-shaped entrances, concave inner walls, overhanging margins and relatively smooth, gently sloping, debris-covered floors (McBride \& Picard 2004; Mellor et al. 1997). The formation of tafoni has been ascribed to differential weathering, granular disintegration and flaking associated with microlithological and microclimatological differences along rock walls. Meteoric water migration through megapores and associated dissolution and reprecipitation of calcareous and saline cements, crystallisation pressure, hydrolysis, hydration and/or diffusion, and wind deflation have also been noted as particular contributors (Cooke, Warren \& Goudie 1993; Martini 1978; Matsukura \& Tanaka 2000; McBride \& Picard 2000; Mellor et al. 1997; Mottershead \& Pye 1994). However, water-based weathering processes may be temporally and spatially constrained at some tafoni sites, such as those reported from arid regions of Antarctica, where thermal stress may take on a more important weathering function (Hall \& André 2006).

The GGHNP hosts a variety of variably sized tafoni forms (ranging from only a few to several tens of cubic metres), which most likely represent various stages of tafoni evolution, as described by Mellor et al. (1997). It would appear that several of the elongated rock shelters (caves) observed in the GGHNP (primarily in Clarens Formation sandstone) formed through the amalgamation of tafoni caverns that are in places separated by thin rock walls. Multiple vertical zones of tafoni and cavern development may occur within rock walls and are likely controlled by zonal lithological (rock hardness) and moisture differences (Matsukura \& Tanaka 2000). The caverns are thought to enlarge in an upward and backward direction, thus potentially capturing subsurface water and causing water flow down the backwall (Mellor et al. 1997), as is frequently observed at sites in the GGHNP. As the tafoni enlarge over time, so the microclimate within the cavern is altered (primarily through greater contrasts in solar radiation levels across rock surfaces), thus influencing rock characteristics such as moisture and temperature. Consequently, different weathering processes may dominate on different parts of tafoni, such as case hardening on outer roof surfaces and granular disintegration on inner cavern surfaces (Mellor et al. 1997).
Another type of cavern occasionally observed in the GGHNP region is the alcove. An alcove has been defined as 'a steepsided, arcuate cavity on the flank of a rock outcrop, typically produced by water erosion processes such as solution and spring sapping or seepage' (Nash 2000:14). Thus, several of the so-called caverns or caves in the GGHNP, and possibly even large tafoni which owe their origin to seepage and dissolution processes, might be classified as alcoves. Water is often found to be seeping out from the rear of these features, producing blackstaining on the backwalls (Figure 4c). However, as Lamb et al. (2006) point out, the origin of alcoves remains unclear given that the ability of seepage to erode bedrock is not yet comprehensively understood, and also because other mechanisms might have contributed to such arcuate cavities.

According to Le Roux (1978), caves in the GGHNP are a consequence of exudation, whereby weathering processes are accelerated at the base of cliffs, in part owing to the presence of shale or clay-bearing sandstone layers. Many of the caverns observed in the GGHNP are located at the lower boundary of the Clarens Formation where it merges with the siltstones and shale beds of the Elliot Formation. Here we observed that brittle fractures are common phenomena, possibly not so much due to weathering in the clay-like rocks, but rather due to mass failure of bedrock below the recess and beyond the dripline of water coming over the cliff (see also Young et al. 2009).

\section{Rock basins (weathering or solutional pits, gnammas)}

Rock basins are relatively circular or oval and usually flatfloored and steep-sided bedrock depressions ranging from a few centimetres to several metres in diameter and depth (Domínguez-Villar et al. 2009) (Figure 4d). Rock basins have also been referred to as gnammas (Domínguez-Villar et al. 2009), weathering pits (Alexandrowicz 1989; DomínguezVillar 2006; Goudie \& Migón 1997), potholes (Chan et al. 2005; Graham \& Wirth 2008; Johnsson 1988), solution pans (Dzulynski \& Kotarba 1979), Opferkessel (Hedges 1969), pias (Vidal Romaní 1989) and, locally, as rock tanks (King 1942) or weathering basins (Cooks \& Pretorius 1987). Rock basins may contain standing water for short durations after rainfall or for several weeks to months during wet periods or seasons. Rock basins, which most typically develop in granite and sandstone, are understood to be polygenetic in origin (DomínguezVillar et al. 2009; Dzulynski \& Kotarba 1979). Processes include chemical weathering associated with dissolution (Domínguez-Villar et al. 2009; Twidale 1982; Wray 1997) and mechanical erosion associated with, for instance, convective (circulatory) currents within the standing water (Dzulynski \& Kotarba 1979), wash and deflation (Alexandrowicz 1989; Graham \& Wirth 2008), undercutting of the rock basin sides (Goudie \& Migón 1997), and the plucking action of lichen thalli during the drying phase (Moses \& Smith 1993). Complex biofilms may accumulate at the base of rock basins; these are known to dissolve the cement between sandstone grains and also act as biological sealants to water infiltration (Chan et al. 2005). Cooks and Pretorius (1987) have identified bluegreen algae below the rock basins' seasonal water lines in the GGHNP and suggested that associated biochemical activity 
would enhance weathering there. Solutional weathering is prominent along joints and bedding planes and may cause intense etching, particularly in quartz-rich sandstone (Young et al. 2009). Cooks and Pretorius (1987) similarly observed rock basin development in the GGHNP at sites where joints intersect at the surface. In addition, some of the pans have well-developed water level notches which are probably the result of solutional attack.

Rock basins in the GGHNP are commonly $15 \mathrm{~cm}-150 \mathrm{~cm}$ wide and approximately $5 \mathrm{~cm}-30 \mathrm{~cm}$ deep. However, Cooks and Pretorius (1987) report features up to $16 \mathrm{~m}$ in length and $1 \mathrm{~m}$ in depth. Examples of isolated deep pits (>1 $\mathrm{m}$ deep) and exceptionally wide (several metres in diameter), shallow bedrock basins (also referred to locally as 'tarns') occur elsewhere on Clarens Formation sandstones, such as in the Sehlabathebe National Park, southern Drakensberg. In some cases spillways develop at the lowest point of the basin rim where erosion eventually produces a confined water exit route, below which drainage microchannels usually develop. The overflow of water during summer is an effective mechanism to remove weathered products accumulating in the rock basins. Less frequently, a staircase of rock basins with connected drainage microchannels may develop down sandstone surfaces, while in other cases closely spaced basins may eventually coalesce. Rock basins may also be associated with incision into polygonally cracked surfaces (Robinson \& Williams 1992) or with raised conical forms such as rock doughnuts (Netoff \& Shroba 2001; Young et al. 2009).

\section{Rock doughnuts}

Rock doughnuts were first described by Blank (1951:822), who described them as 'weather pits of various sizes on granite' which are 'surrounded by raised annular rims'. Although rock doughnuts are relatively rare phenomena which have received little research attention, they have also been reported from a variety of sandstone terrains in Australia (Twidale \& Campbell 1998; Young et al. 2009) and from south-eastern Utah, USA (Netoff \& Shroba 2001). Rock doughnuts belong to a group of conical-shaped raised landforms with a central summit 'pit' or rock basin, examples of which were found at one locality in the GGHNP (Figures 3 and 5a). Rock doughnuts ranging between $5 \mathrm{~cm}$ and several metres high have been reported in Australia and the USA and have pit diameters ranging from approximately $20 \mathrm{~cm}$ to $10 \mathrm{~m}$ (Netoff \& Shroba 2001; Twidale \& Campbell 1998; Young et al. 2009). The ones in the GGHNP are typically
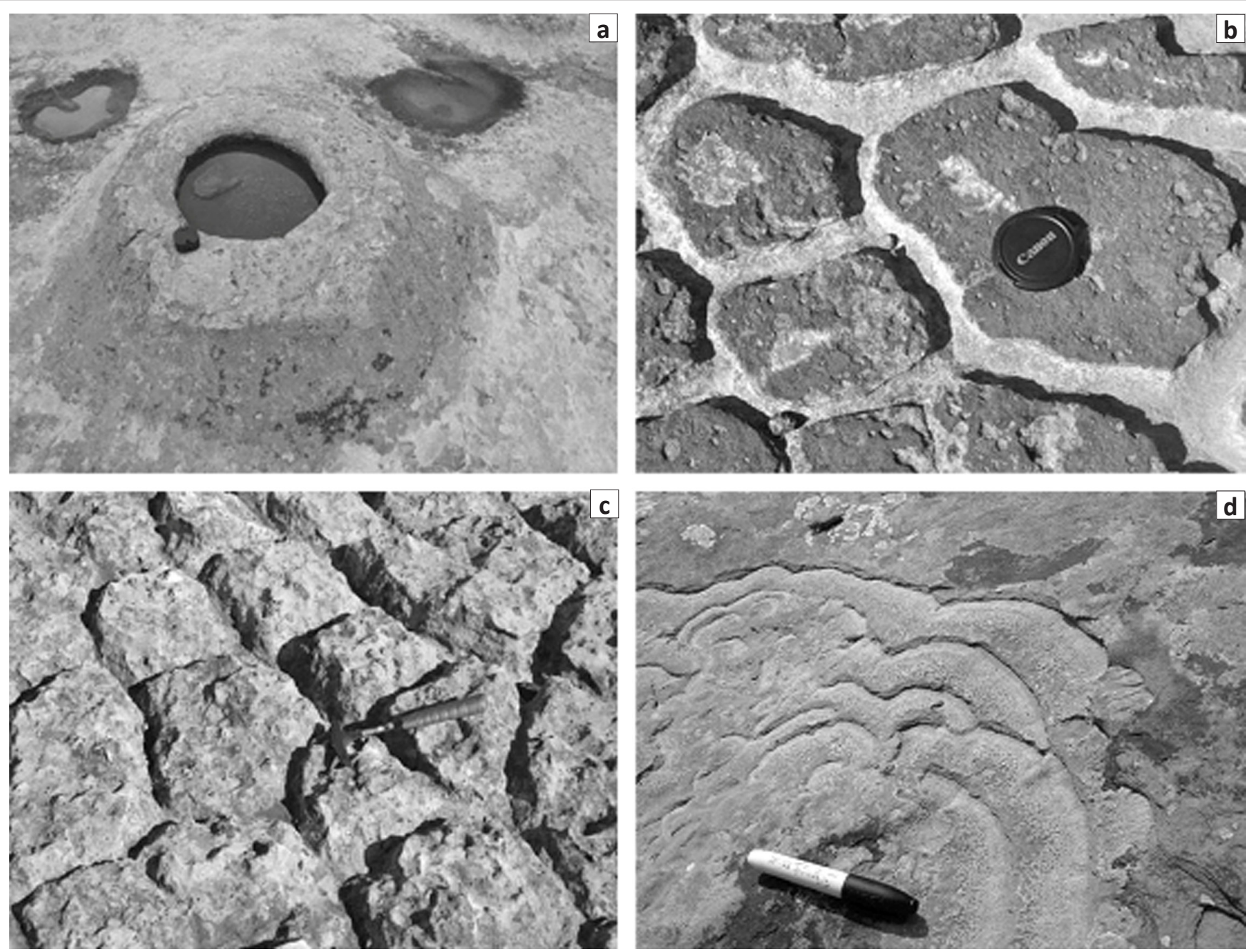

FIGURE 5: (a) A rock doughnut, (b) polygonal 'boxwork' structures, (c) convex polygonal structures and (d) lichen etching into Clarens Formation sandstone in the Golden Gate Highlands National Park. 
$5 \mathrm{~cm}-50 \mathrm{~cm}$ high and have pit diameters ranging from $15 \mathrm{~cm}$ to $60 \mathrm{~cm}$. Although reasons for the formation of rock doughnuts remain uncertain, Twidale and Campbell (1998) suggest that subsurface water held in the regolith was preferentially drained from zones adjacent to basins (doughnuts). The drained areas consequently had less moisture and thus weathered less rapidly than adjacent areas where more water was retained.

\section{Polygonal cracking (tessellation or alligator cracking)}

Polygonal fracture patterns consist mainly of pentagonal or hexagonal cracks meeting at ca $120^{\circ}$ angles where they make tri-radial junctions on predominantly curved rock surface pavements (Robinson \& Williams 1989, 1992; Young et al. 2009). Polygonal crack diameters may vary from $5 \mathrm{~cm}$ to more than $50 \mathrm{~cm}$ and in some instances micropolygonal cracking has been observed within larger tessellation plates (Robinson \& Williams 1989). Although understanding the origin of tessellation has caused some debate (Young et al. 2009) and may differ between sites, it is a particularly common phenomenon in case-hardened rocks associated with regions of seasonal precipitation patterns (Robinson \& Williams 1989, 1992; Twidale \& Campbell 1993). Some of the likely causative mechanisms suggested include shrinkage of silica gel due to changing thermal and/or moisture conditions on the rock surface (Robinson \& Williams 1989, 1992). These include thermal changes that set up differential surface stress (Branagan 1983; Croll 2009), expansion to accommodate precipitating solutions of iron, and thermal stresses or geochemical changes caused by emplacement of dolerite dykes (Velázquez et al. 2008).

Polygonal cracking is a common phenomenon in the GGHNP and in most instances occurs on horizontal case-hardened rock pavements, but may also be observed on vertical exposures such as at the base of cliffs along the Echo Ravine hiking trail and at Baboon Ridge. As observed in the field, the cracks may penetrate beyond the ca 5-mm thick case-hardened surface and continue further into the subsurface. At the Oribi Drive vulture site and also at Baboon Ridge, well-developed pavements occur in sandstones close to dolerite dykes. Less common are polygonal 'boxwork' structures where the joints are positive features, possibly due to silica induration along the joints, while the polygonal cells have been preferentially eroded to form small rock basins (Figure $5 b$ ).

\section{Bedrock drainage microchannels (fluting, gutters, karren forms)}

Bedrock drainage microchannels most frequently develop on limestone, dolomite and other soluble rock types. They are, however, also known to form on basaltic, granitic and sandstone surfaces as a result of sheet or channelised water flow across bedrock surfaces (forming rillenkarren or'solution flutes' and rinnenkarren or rundkarren, respectively). The formation of such structures is primarily due to dissolution and biokarstic processes and/or the pre-existence of joints or surface irregularities (Crowther 1997; Dunkerley 1979; Fiol, Fornós \& Ginés 1996; Wray 1997). In some instances long drainage microchannels are interrupted by shallow rock basins. Sandstone surfaces with ferruginous concretions are common to the GGHNP and often lead to intricate surface drainage across bedrock, producing sharp-crested and highly fragmented surfaces. Trittkarren are much rarer and lesserknown weathering and erosion surface forms and have been described as 'small arcuate impressions' on sloping bedrock (Vincent 1983:205). Although examples of trittkarren have been observed in the GGHNP, their precise process origins remain poorly understood. However, Bögli (1960) suggested that such forms may develop where solution rates are influenced by the slow dissolution of gaseous $\mathrm{CO}_{2}$ into the surface water in contact with bedrock and subsequently, when the microforms are established, they initiate selfsustaining processes such as concentrated overland flow towards the centre of each riser lip (Bögli 1980).

Twidale (1980) first described incised channelling into sandstone in the Drakensberg and suggested it to be the product of subsurface flow beneath a soil cover before the sandstone had been exposed. However, it is now more generally recognised that such sandstone channels (up to $100 \mathrm{~mm}$ wide and $10 \mathrm{~mm}$ deep) represent selective channelised drainage routes across rock surfaces (Robinson \& Williams 1992; Wray 1997). Polygonally cracked surfaces permit drainage along the cracks, consequently accelerating erosion and eventually leading to well-incised bedrock microchannels, which grow in diameter and depth in the downflow direction. Observations at a site in the GGHNP indicate that originally fairly flat polygonally cracked surfaces may evolve into a more dramatically undulating micro-relief of incised channels (mean depth $=7 \mathrm{~cm} ; n=20$ ) that separate broad convex polygonal tops with an average diameter of $33 \mathrm{~cm}(n=40)$ (Figure $5 c$ ).

\section{Lichens and weathering}

Although it has previously been argued that lichens may protect rocks from enhanced weathering (Danin \& Garty 1983), the more common view is that lichens promote rock weathering through chemical and mechanical processes which include metallic cation chelation, dissolution, swelling of organic and inorganic salts, and hyphal penetration, where expansion and contraction cause the detachment, incorporation and expulsion of rock flakes (Chen et al. 2000; McCarroll \& Viles 1995). Wessels et al. (1995) have measured high strain on Clarens Formation sandstone surfaces in the GGHNP in association with increasing moisture uptake by some endolithic lichens, particularly at the thallus rim. In another study undertaken in the GGHNP, Wessels and Wessels (1991) identified bagworm larvae constructing their bags around lichen-weathered quartz crystals and thus demonstrated that lichen-induced weathering may operate synergistically with other biogenic processes on rock surfaces.

Studies, including some from the GGHNP, have indicated that some lichens may form circular or crescentic depressions bounded by microscarps on rock surfaces (Wessels \& Schoeman 1988; Wessels et al. 1995) (Figure 5d) owing to the combined actions of chemical weathering by chelation and mechanical disintegration associated with the penetration and expansion of hyphae (Cooks \& Otto 1990; McKechnie, Grab \& Drennan 2007; Moses \& Smith 1993). Many of the flat 
or gently sloping sandstone pavements in the GGHNP are extensively covered with circular patches of endolithic lichen thalli. When these thalli merge, they can produce remarkable flower-like patterns of pits in the rock surface (Figure $5 \mathrm{~d}$ ). Broadly similar forms have been recorded from the High Atlas Mountains in Morocco (Edwards et al. 2002). A survey undertaken on a rock wall in the GGHNP found that up to $29 \%$ of the colonisable surface was covered by thalli (Wessels \& Schoeman 1988). Our own surveys supported this observation. The associated thalli microdepressions observed in the GGHNP include compound (i.e. microscarps), coalescent and crescentic forms.

Lichenometric dating has become a common method for determining the relative age of exposed rock surfaces and has assisted in providing indications of glacial advances (Bradwell 2004), the timing of debris flows (Innes 1983), rates of fluvial downcutting (Thompson \& Jones 1986) and past rockfall events (Bull 1996), to name a few. Surface age is traditionally determined by the single largest lichen, but other methods such as using the gradient of the lichen size-frequency distribution have also been used to produce well-calibrated dating curves (Bradwell 2004). Wessels and Schoeman (1988) examined freshly quarried Clarens Formation sandstone blocks used in the construction of a stone wall in 1942 to determine rates of lichen-induced weathering in the GGHNP. Their results suggest a theoretical mean surface denudation rate of $9.6 \mathrm{~mm}$ per 100 years where endolithic lichens are active on rock surfaces. Observations at the same site (the Glen Reenen graveyard) in 2009 showed that such lichen attack still continues. We measured 29 lichens (Lecidea aff. sarcogynoides) on 16 blocks and found that the average width of the lichens was $98.28 \mathrm{~mm}$ and that they penetrated into the rock surface to an average maximum depth of $4.8 \mathrm{~mm}$. The average maximum rate of lichen denudation in the 67 years since 1942 was thus $7.16 \mathrm{~mm}$ per 100 years. Such results may prove valuable for any future attempt to determine the relative lichenometric-derived ages of mass movement phenomena in the GGHNP.

The depths of lichen denudation at Glen Reenen are not unique. For example, at a Clarens Formation sandstone at Baboon Ridge we measured 30 Lecidea pits and found that the average maximum width was $127 \mathrm{~mm}$ and the average maximum depth was $5.8 \mathrm{~mm}$. At Red Mountain we measured 20 Lecidea pits in Elliot Formation sandstone and found that the comparable values were $65.25 \mathrm{~mm}$ and $3.3 \mathrm{~mm}$, respectively.

\section{Discussion and conclusion}

Why does the GGHNP have such a rich diversity of macroand microscale sandstone phenomena? Warke, McKinley and Smith (2006) have experimentally demonstrated that even minor structural and mineralogical differences between sandstone samples can result in substantially different weathering behaviours and consequent rock morphological outcomes. The GGHNP and foothills to the east of the Great Escarpment along KwaZulu-Natal and the Eastern Cape host a particularly dynamic assortment of sandstones, ranging from fine-grained mudstones and siltstones to coarse-grained quartzitic sandstones. Given the relative abundance of feldspathic sandstones in the GGHNP, many of the macro- and microscale phenomena observed resemble those commonly recorded in granitic terrain. The presence of ferruginous chloritic mud and calcitic cement (Eriksson 1981) has provided the catalyst to the wide assortment of landforms associated with dissolution, which more typically occur in limestone or dolomitic terrain. Further, the rich diversity of the sandstone depositional history and concurrent neotectonics have provided for an equally complex spatial diversity of sandstone porosity, degree of lithification, and bedding and jointing characteristics, all of which contribute to sedimentary constructions and destructions. Finally, neither the past nor present climate can be underestimated for its all-important role in developing geomorphic phenomena through weathering, erosion and deposition of earth materials. The larger landforms (i.e. cliffs, pillars, arches, etc.) discussed in this paper are the likely product of past geological processes and controls and climate-driven geomorphic processes operating at geological timescales, while the smaller microforms (i.e. honeycombs, rock basins, polygonal cracks, etc.) are likely consequences of more recent climates (i.e. from the last few thousand years), characterised in particular by strong seasonal temperature and moisture differences.

Considerable work has focused on the deterioration of sandstone cultural rock, particularly in the context of monuments that belong to world cultural heritage (Mohammadi \& Krumbein 2008) and sandstone buildings (Viles 2002). The rapid deterioration of sandstone containing rock art both locally (Hall, Meiklejohn \& Arocena 2007; Meiklejohn 1997) and internationally (Benito et al. 1993; Walderhaug 1998) has also been a matter of concern in the GGHNP. The primary geomorphic causes for rock art deterioration are granular disintegration and flaking associated with salt crystallisation, hydration, wetting and drying, and chemical alterations (Benito et al. 1993; Meiklejohn 1997; Meiklejohn, Hall \& Davis 2009). However, it should be recognised that for the most part, rock weathering is a natural process, and as Pope, Meierding and Paradise (2002:224) convey: 'geomorphic processes are integral in the creation of the "ruined" aesthetic'. Notwithstanding this, rock art requires preservation against unnecessary accelerated weathering, particularly where anthropogenic contributing factors are part of the cause.

Finally, an improved understanding of the mechanisms producing terrestrial sandstone phenomena, such as those described for the GGHNP, offers opportunities to better understand sedimentary and weathering processes on other planets such as Mars (Chan et al. 2008). Some of the common sandstone phenomena identified in the GGHNP and on Mars include surface flaking (exfoliation), case hardening, honeycombs, tafoni, 'blueberries' and polygonal cracking. The water-based mechanism for blueberry formation on Earth has been used as a terrestrial analogue for Martian blueberry formation and, more importantly, to provide possible evidence for the past or present occurrence of fluids on Mars (Squyres \& Knoll 2005). 
We hope that this work has extended scientific knowledge on sandstone phenomena in the GGHNP and thus provides a contribution to geoconservation and the regional geotourism industry through the provision of educational materials.

\section{Acknowledgements}

We thank South African National Parks for permission to carry out research at the GGHNP. Particular thanks to the manager of the GGHNP, Johan Taljaard, for his kind assistance and permission to use the photographic image of the natural stone bridge. S.G. acknowledges financial support from the Wits University Research Committee. Wendy Job kindly assisted in the cartographic production. We also appreciate the valuable comments and suggestions by the referees.

\section{References}

Alexandrowicz, Z., 1989, 'Evolution and weathering of pits on sandstone tors in the Polish Carpathians', Zeitschrift für Geomorphologie 33, 275-289.

Benito, G., Machado, M.J. \& Sancho, C., 1993, 'Sandstone weathering processes damaging prehistoric rock paintings at the Albarracin Cultural Park, NE Spain' Environmental Geology 22, 71-79. doi:10.1007/BF00775287

Blank, H.R., 1951, 'Rock doughnuts, a product of granite weathering', American Journal of Science 249, 822-829. doi:10.2475/ajs.249.11.822

Bögli, A., 1960, 'Kalkösung und Karrenbildung [Calcification and solution flute development]', Zeitschrift für Geomorphologie Suppl. 2, 4-21.

Bögli, A., 1980, Karst hydrology and physical speleology, Springer-Verlag, Berlin.

Bordy, E.M., Hancox, P.J. \& Rubidge, B.S., 2004, 'Fluvial style variations in the Late Triassic - Early Jurassic Elliot formation, main Karoo Basin, South Africa', Journal of African Earth Sciences 38, 383-400. doi:10.1016/j.jafrearsci.2004.02.004

Bradwell, T., 2004, 'Lichenometric dating in southeast Iceland: the sizefrequency approach', Geografiska Annaler 86A, 31-41, doi:10.1111/j.04353676.2004.00211.x

Branagan, D.F., 1983, 'Tesselated pavements', in R.W. Young \& G.C. Nanson (eds.), Aspects of Australian sandstone landscapes, pp. 11-20, Australian and New Zealand Geomorphology Group, Wollongong.

Büdel, B., Weber, B., Kühl, M., Pfanz, H., Sültemeyer, D. \& Wessels, D., 2004, 'Reshaping of sandstone surfaces by cryptoendolithic cyanobacteria: bioalkalization causes chemical weathering in arid landscapes', Geobiology 2, 261-268. doi:10.1111/ j.1472-4677.2004.00040.x

Bull, W.B., 1996, 'Dating San Andreas fault earthquakes with lichenometry', Geology 24, 111-114. doi:10.1130/0091-7613(1996)024<0111:DSAFEW>2.3.CO;2

Campbell, S.W., 1999, 'Chemical weathering associated with tafoni at Papago Park, central Arizona', Earth Surface Processes and Landforms 24, 271-278. doi:10.1002/(SICI)1096-9837(199903)24:3<271::AID-ESP969>3.3.CO;2-K, doi:10.1002/(SICI)1096-9837(199903)24:3<271::AID-ESP969>3.0.CO;2-T

Catuneanu, O., Hancox, P.J. \& Rubidge, B.S., 1998, 'Reciprocal flexural behaviour and contrasting stratigraphies: a new basin development model for the Karoo retroarc foreland system, South Africa', Basin Research 10, 417-439. doi:10.1046/j.1365 2117.1998.00078.x

Catuneanu, O., Hancox, P.J., Cairncross, B. \& Rubidge, B.S., 2002, 'Foredeep submarine fans and forebulge deltas: orogenic off-loading in the underfilled Karoo Basin', Journal of African Earth Sciences 35, 489-502. doi:10.1016/S08995362(02)00154-9

Chan, M.A., Beitler Bowen, B., Parry, W.T., Ormö, J. \& Komatsu, G., 2005, 'Red rock and red planet diagenesis: comparisons of Earth and Mars concretions', GSA Today 15,
$4-10$. doi:10.1130/1052-5173(2005)15[4:RRARPD]2.0.CO;2, doi:10.1130/10524-10. doi:10.1130/1052-5173(2005)15
5173(2005)015[4:RRARPD]2.0.CO;2

Chan, M.A., Yonkee, W.A., Netoff, D.I., Seiler, W.M. \& Ford, R.L., 2008, 'Polygonal cracks in bedrock on Earth and Mars: implications for weathering', Icarus 194 cracks in bedrock on Earth and Mars: im

Chen, J., Blume, H.P. \& Beyer, L., 2000, 'Weathering of rocks induced by lichen colonization - a review', Catena 39, 121-146. doi:10.1016/S0341-8162(99)00085-5

Cooke, R., Warren, A. \& Goudie, A., 1993, Desert geomorphology, UCL Press, London.

Cooks, J. \& Pretorius, J.R., 1987, 'Weathering basins in the Clarens Formation Sandstone, South Africa', South African Journal of Geology 90, 147-154.

Cooks, J. \& Otto, R., 1990, 'The weathering effects of the lichen Lecidea aff. sarcogynoides (Koreb.) on Magaliesberg quartzite', Earth Surface Processes and sarcogynoides (Koreb.) on Magaliesberg quartzite', Earth
Landforms 15, 491-500. doi:10.1002/esp.3290150602

Croll, J.G.A., 2009, 'Possible role of thermal ratcheting in alligator cracking of asphalt pavements', International Journal of Pavement Engineering 10, 447-453. doi:10.1080/10298430902730547
Crowther, J., 1997, 'Surface roughness and the evolution of karren forms at Lluc, Serra de Tramuntana, Mallorca', Zeitschrift für Geomorphologie 41, 393-407.

Danin, A. \& Garty, J., 1983, 'Distribution of cyanobacteria and lichens on hillsides of the Negev Highlands and their impact on biogenic weathering', Zeitschrift für Geomorphologie 27, 423-444.

Demek, J., 1964, 'Slope development in granite areas of Bohemian Massif (Czechoslovakia)', Zeitschrift für Geomorphologie Suppl. 5, 83-106.

Domínguez-Villar, D., 2006, 'Early formation of gnammas (weathering pits) in a recently glaciated area of Torres del Paine, southern Patagonia (Chile)', Geomorphology 76 137-147. doi:10.1016/j.geomorph.2005.10.006

Domínguez-Villar, D., Razola, L., Carrasco, R.M., Jennings, C.E. \& Pedraza, J., 2009, 'Weathering phases recorded by gnammas developed since last glaciation at Serra da Estrela, Portugal', Quaternary Research 72, 218-228. doi:10.1016/j. yqres.2009.05.004

Dorn, R.I., 2004, 'Case hardening', in A.S. Goudie (ed.), Encyclopedia of geomorphology, vol. 1, pp. 118-119, Routledge, London.

Du Preez, P.J. \& Bredenkamp, G.J., 1991, 'Vegetation classes of the southern and eastern Orange Free State (Republic of South Africa) and the highlands of Lesotho', Navorsinge van die Nasionale Museum Bloemfontein 7, 477-526.

Dunkerley, D.L., 1979, 'The morphology and development of rillenkarren', Zeitschrift für Geomorphologie 23, 332-348.

Dzulynski, S. \& Kotarba, A., 1979, 'Solution pans and their bearing on the development of pediments and tors in granite', Zeitschrift für Geomorphologie 23, 172-191.

Edwards, H.G.M., Holder, J.M., Seaward, M.R.D. \& Robinson, D.A., 2002, 'A Raman spectroscopic study of lichen-assisted weathering of sandstone outcrops in the High Atlas Mountains, Morocco', Journal of Raman Spectroscopy 33, 449-454. doi:10.1002/jrs.859

Ericksson, P.G., 1981, 'A palaeoenvironmental analysis of the Clarens Formation in the Natal Drakensberg', Transactions of the Geological Society of South Africa 84 7-17.

Ericksson, P.G., 1984, 'A palaeoenvironmental analysis of the Molteno Formation in the Natal Drakensberg', Transactions of the Geological Society of South Africa 87, 237-244.

Ericksson, P.G., 1985, 'The depositional environment of the Elliot Formation in the Natal Drakensberg and north-east Orange Free State', Transactions of the Geological Society of South Africa 88, 19-26.

Fairbridge, R.W. (ed.), 1968, The encyclopedia of geomorphology, Reinhold, New York.

Fiol, L., Fornós, J.J. \& Ginés, A., 1996, 'Effects of biokarstic processes on the development of solutional rillenkarren in limestone rocks', Earth Surface Processes and
Landforms 21, 447-452. doi:10.1002/(SICI)1096-9837(199605)21:5<447::AIDLandforms 21, $447-4$
ESP607>3.0.CO;2-X

Goudie, A.S. \& Migón, P., 1997, 'Weathering pits in the Spitzkoppe area, central Namib desert', Zeitschrift für Geomorphologie 41, 417-444.

Goudie, A.S. \& Viles, H.A., 1997, Salt weathering hazard, John Wiley \& Sons, Chichester.

Goudie, A.S., Migón, P., Allison, R.J. \& Rosser, N., 2002, 'Sandstone geomorphology of the AI Quwayra area of south Jordan', Zeitschrift für Geomorphologie 46, 365-490.

Graham, T.B. \& Wirth, D., 2008, 'Dispersal of large branchiopod cysts: potential movement by wind from potholes on the Colorado Plateau', Hydrobiologia 600 17-27. doi:10.1007/s10750-007-9171-5

Grisez, L., 1960, 'Alveolisation littorale de schistes metamorphiques [Alveolisation of coastal metamorphic schists]', Révue de Géomorphologie Dynamic 11, 164-167.

Groenewald, G.H., 1986, 'Geology of the Golden Gate Highlands National Park', Koedoe 29, 165-181.

Hall, K. \& André, M.-F., 2006, 'Temperature observations in Antarctic tafoni: implications for weathering, biological colonization, and tafoni formation', Antarctic Science 18, 377-384. doi:10.1017/S0954102006000423

Hall, K., Marker, M.E. \& Le Roux, J.S., 1991, 'The significance of periglacial geomorphology in southern Africa: a discussion', South African Geographer 18 134-139.

Hall, K., Meiklejohn, I. \& Arocena, J., 2007, 'The thermal responses of rock art pigments: implications for rock art weathering in southern Africa', Geomorphology 91, 132-145. doi:10.1016/j.geomorph.2007.02.002

Hedges, J., 1969, 'Opferkessel [Rock basins]', Zeitschrift für Geomorphologie 13, 22-55.

Henderson, Z., Scott, L., Rossouw, L. \& Jacobs, Z., 2006, 'Dating, paleoenvironments, and archaeology: a progress report on the Sunnyside 1 site, Clarens, South Africa', and archaeology: a progress report on the Sunnyside 1 site, Clarens, South Africa', Archaeological Papers of the Am
doi:10.1525/ap3a.2006.16.1.139

Holmer, B., 1998, 'Flaking by insolation drying and salt weathering on the Swedish west coast', Zeitschrift für Geomorphologie 42, 39-55.

Holzförster, F., 2007, 'Lithology and depositional environments of Lower Jurassic Clarens Formation in the eastern Cape, South Africa', South African Journal of Geology 110, 543-560. doi:10.2113/gssajg.110.4.543

Innes, J.L., 1983, 'Size-frequency distributions as a lichenometric technique: an assessment', Arctic and Alpine Research 15, 285-294. doi:10.2307/1550825

Irwin, R.P., Fortezzo, C.M., Tooth, S.E., Howard, A.D., Zimbelman, J.R., Barnhart, C.J., et al., 2009, 'Origin of theater-headed tributaries to Escalalante and Glen Canyons, Utah', [poster] presentation at the 40th Lunar and Planetary Science Conference (Lunar and Planetary Science XL), The Woodlands, Texas, 23-27th March.

Jennings, J.N., 1968, 'Tafoni', in R.W. Fairbridge (ed.), The encyclopedia of geomorphology, p. 1104, Reinhold, New York. 
Johnsson, G., 1988, 'Potholes-glacial and non-glacial cavities', Geografiska Annaler 70A, 333-336. doi:10.2307/521266

Kay, C., Bredenkamp, G.C. \& Theron, G.K., 1993, 'The plant communities of the Golden Gate Highlands National Park in the north-eastern Orange Free State', South African Journal of Botany 59, 442-449.

King, L.C., 1942, South African Scenery, Oliver and Boyd, Edinburgh.

Kitching, J.W. \& Raath, M.A., 1984, 'Fossils from the Elliot and Clarens Formations (Karoo Sequence) of the northeastern Cape, Orange Free State and Lesotho, and a suggested biozonation based on tetrapods', Palaeoentologia Africana 25 111-125.

Lamb, M.P., Howard, A.D., Johnson, J., Whipple, K.X., Dietrich, W.E. \& Perron, J.T. 2006, 'Can springs cut canyons into rock?', Journal of Geophysical Research 111, EO7002. doi:10.1029/2005JE002663

Lambert, D., 1980, 'The influence of ground water salts in the formation of sandstone shelters near Gosford, NSW', Institute for Conservation of Cultural Materials Bulletin 6, 29-34.

Le Roux, J.S., 1978, 'Die ontstaan van grotte en holtes in die kranse van die Clarenssandsteenformasie in die Golden Gate-gebied [Formation of caves and hollows in the cliffs of the Clarens Sandstone Formation in the Golden Gate area]', South African Geographer 61, 23-29.

Le Roux, J.S. \& Marker, M.E., 1990, 'Discussion of periglacial geomorphology at Golden Gate Highlands National Park, Orange Free State, South Africa', South African Geographer 17, 129-131.

Leasure, V.L., Kind, T.C. \& Busby, M.R., 2007, 'Formation of Apex natural arch, Kentucky', Journal of the Kentucky Academy of Science 68, 96-101. doi:10.3101/10987096(2007)68[96:FOANAA]2.0.CO;2

Mahaney, W.C., Milner, M.W., Netoff, D., Dohn, J., Kalm, V., Krinsley, D., et al., 2008, 'Blueberries on Earth and Mars: correlations between concretions in Navajo Sandstone and Terra Meridiani on Mars', presentation at the American Geophysical Union Fall Meeting (abstract no. P33B-1440), San Francisco, 15-19th December.

Marker, M.E., 1989, 'Periglacial geomorphology at Golden Gate Highlands Nationa Park: a note on its fieldwork potential', South African Geographer 16, 147-153.

Marker, M.E., 1990, 'Nivation evidence from a north-facing slope? Golden Gate, eastern Orange Free State', South African Geographical Journal 72, 15-18.

Martini, I.P., 1978, 'Tafoni weathering, with examples from Tuscany, Italy', Zeitschrift für Geomorphologie 22, 44-67.

Matsukura, Y. \& Tanaka, Y., 2000, 'Effect of rock hardness and moisture content on tafoni weathering in the granite of Mount Doeg-sung, Korea', Geografiska Annale 82A, 59-67. doi:10.1111/j.0435-3676.2000.00112.x

McBride, E.F. \& Picard, M.D., 2000, 'Origin and development of tafoni in Tunnel Spring Tuff (Oligocene), Crystal Peak, Utah', Earth Surface Processes and Landforms 25 , 869-879. doi:10.1002/1096-9837(200008)25:8<869::AID-ESP104>3.0.CO;2-F

McBride, E.F. \& Picard, M.D., 2004, 'Origin of honeycombs and related weathering forms in Oligocene Macigno Sandstone, Tuscan coast near Livorno, Italy', Earth Surface Processes and Landforms 29, 713-735. doi:10.1002/esp.1065

McCarroll, D. \& Viles, H., 1995, 'Rock-weathering by the lichen Lecidea auriculata in an arctic alpine environment', Earth Surface Processes and Landforms 20, 199-206. doi:10.1002/esp.3290200302

McKechnie, C., Grab, S. \& Drennan, G., 2007, 'Documenting lichen-induced mechanical weathering of quartzitic sandstone at Kaapsehoop, Mpumalanga', South African Journal of Science 103, 117-120.

Meiklejohn, K.I., 1997, 'The role of moisture in the weathering of the Clarens Formation of the KwaZulu-Natal Drakensberg: implications for the preservation of indigenous rock art', South African Geographical Journal 79 (Special Issue), of indigenou
$199-206$.

Meiklejohn, K.I., Hall, K. \& Davis, J.K., 2009, 'Weathering of rock art at two sites in the KwaZulu-Natal Drakensberg, southern Africa', Journal of Archaeological Science 36, 973-979. doi:10.1016/j.jas.2008.11.020

Mellor, A., Short, J. \& Kirkby, S.J., 1997, 'Tafoni in the El Chorro area, Andalucia, southern Spain', Earth Surface Processes and Landforms 22, 817-833. doi:10.1002/ (SICI)1096-9837(199709)22:9<817::AID-ESP768>3.0.CO;2-T.

Mohammadi, P. \& Krumbein, W.E., 2008, 'Biodeterioration of ancient stone materials from the Persepolis monuments (Iran)', Aerobiologia 24, 27-33. doi:10.1007/ s10453-007-9079-6

Moon, B.P., 1991, 'The significance of rectilinear bedrock slopes', South African Journal of Science 87, 208-210.

Moon, B.P. \& Munro-Perry, P.M., 1988, 'Slope development on the Clarens Sandstone Formation in the northeastern Orange Free State', The South African Geographical Journal 70, 57-68.

Moses, C.A. \& Smith, B.J., 1993, 'A note on the role of the lichen Collema auriforma in solution basin development on a Carboniferous limestone substrate', Earth Surface Processes and Landforms 18, 363-368. doi:10.1002/esp.3290180405

Mottershead, D.N. \& Pye, K., 1994, 'Tafoni on coastal slopes, south Devon, UK', Earth Surface Processes and Landforms 19, 543-563. doi:10.1002/esp.3290190607

Mueller, J.E. \& Twidale, C.R., 2002, 'Geomorphic development of the Giants of the Mimbres, Grant County, New Mexico', New Mexico Geology 24, 39-48.

Mustoe, G.E., 1982, 'The origin of honeycomb weathering', Bulletin of the Geological Society of America 93, 108-115. doi:10.1130/00167606(1982)93<108:TOOHW>2.0.CO;2

Nash, D.J., 2000, 'Alcoves', in D.S.G. Thomas \& A. Goudie (eds.), The dictionary of physical geography, 3rd edn., p. 14, Blackwell, Oxford.
Netoff, D.I. \& Shroba, R.R., 2001, 'Conical sandstone landforms cored with clastic pipes in Glen Canyon National Recreation Area, southeastern Utah', Geomorphology 39, 99-110. doi:10.1016/S0169-555X(00)00096-9

Nicol, I.G., 1973, 'Land forms in the Little Caledon Valley, Orange Free State', South African Geographical Journal 55, 56-68.

Ollier, C.D., 1978, 'Induced fracture and granite landforms', Zeitschrift für Geomorphologie 22, 249-257.

Paradise, T.R., 2002, 'Sandstone weathering and aspect in Petra, Jordan', Zeitschrift für Geomorphologie 46, 1-17.

Partridge, T.C. \& Maud, R.R., 1987, 'Geomorphic evolution of southern Africa since the Mesozoic', South African Journal of Geology 90, 179-208.

Pope, G.A., Meierding, T.C. \& Paradise, T.R., 2002, 'Geomorphology's role in the study of weathering of cultural stone', Geomorphology 47, 211-225. doi:10.1016/ S0169-555X(02)00098-3

Reimold, W.U., Whitfield, G. \& Wallmach, T., 2005, 'Geotourism potential of southern Africa', in R.K. Dowling \& D. Newsome (eds.), Geotourism: sustainability, impacts and management, pp. 40-62, Elsevier, Oxford.

Robinson, D.A. \& Williams, R.B.G., 1987, 'Surface crusting of sandstones in southern England and northern France', in V. Gardiner (ed.), International geomorphology 1986, vol. 2, pp. 623-635, Wiley, Chichester.

Robinson, D.A. \& Williams, R.B.G., 1989, 'Polygonal cracking of sandstone at Fontainebleau, France', Zeitschrift für Geomorphologie 33, 59-72.

Robinson, D.A. \& Williams, R.B.G., 1992, 'Sandstone weathering in the High Atlas, Morocco', Zeitschrift für Geomorphologie 36, 413-429.

Robinson, D.A. \& Williams, R.B.G., 1994, 'Sandstone weathering and landforms in Britain and Europe', in D.A. Robinson \& R.B.G. Williams (eds.), Rock weathering and landform evolution, pp. 371-392, John Wiley and Sons, Chichester.

Rodriguez-Navarro, C., Doehne, E. \& Sebastian, E., 1999, 'Origins of honeycomb weathering: role of salts and wind', Geological Society of America Bulletin 111 1250-1255. doi:10.1130/0016-7606(1999)111<1250:OOHWTR>2.3.CO;2

Rowsell, D.M. \& De Swardt, A.M.J., 1976, 'Diagenesis in Cape and Karoo sediments, South Africa and its bearing on their hydrocarbon potential', Transactions of the Geological Society of South Africa 85, 203-210.

SANParks, 2004, Golden Gate Highlands National Park, viewed 12 March 2007, from http://www.sanparks.co.za/parks/golden_gate/.

Smith, R.M.H., Turner, B.R., Hancox, P.J., Rubidge, B.R. \& Catuneanu, O. (eds.), 1998, Trans-Karoo II: 100 million years of changing terrestrial environments in the main Karoo Basin. Guidebook, Gondwana-10 International Conference, University of Cape Town, Cape Town.

Spies, J.J., 1969, 'Die geologiese en geomorfologiese geskiedenis van Golden Gate Hoogland Nasionale Park [The geological and geomorphological history of the Golden Gate Highlands National Park]', Koedoe 12, 184-198.

Squyres, S.W. \& Knoll, A.H., 2005, 'Sedimentary rocks at Meridiani Planum: origin diagenesis, and implications for life on Mars', Earth and Planetary Science Letters 240, 1-10. doi:10.1016/j.epsl.2005.09.038

Svensen, H., Jamtveit, B., Planke, S. \& Chevallier, L., 2006, 'Structure and evolution of hydrothermal vent complexes in the Karoo Basin, South Africa', Journal of the Geological Society London 163, 671-682. doi:10.1144/1144-764905-037

Thompson, A. \& Jones, A., 1986, 'Rates and causes of proglacial river terrace formation in southeast Iceland: an application of lichenometric dating techniques', Boreas 15, 231-246. doi:10.1111/j.1502-3885.1986.tb00928.x

Turkington, A.V. \& Phillips, J.D., 2004, 'Cavernous weathering, dynamical instability and self-organization', Earth Surface Processes and Landforms 29, 665-675. doi:10.1002/esp.1060

Twidale, C.R., 1980, 'Origin of minor sandstone landforms', Erdkunde 34, 219-224. doi:10.3112/erdkunde.1980.03.07

Twidale, C.R., 1982, Granite landforms, Elsevier, New York.

Twidale, C.R. \& Campbell, E.M., 1992, 'On the origin of pedestal rocks', Zeitschrift für Geomorphologie 36, 1-13.

Twidale, C.R. \& Campbell, E.M., 1993, 'Fractures: a double edged sword: a note on fracture density and its importance', Zeitschrift für Geomorphologie 37, 459-475.

Twidale, C.R. \& Campbell, E.M., 1998, 'Development of a basin, doughnut and font assemblage on a sandstone coast, Western Eyre Peninsula, South Australia', Journal of Coastal Research 14, 1385-1394.

Twidale, C.R. \& Vidal Romaní, J.R., 2005, Landforms and geology of granite terrains, Balkema, Leiden. doi:10.1201/9781439833704

Velázquez, A.F., Giannini, P.C.F., Riccomini, C., Sallun, A.E.M., Hachiro, J. \& Gomez, C. de B., 2008, 'Columnar joints in the Patiño formation sandstones, Eastern Paraguay: A dynamic interaction between dyke intrusion, quartz dissolution and cooling-induced fractures', Episodes 31, 302-308.

Vidal Romaní, J.R., 1989, 'Geomorfologia granitica en Galicia (NW España) [Granitic geomorphology in Galicia (NW Spain)]', Laboratorio Xeolóxico de Laxe (Coruña) 13, 89-163.

Viles, H.A., 2002, 'Implications of future climate change for stone deterioration', in S. Siegesund, T.N. Weiss and A. Vollbrecht (eds.), Natural stone, weathering phenomena, conservation strategies and case studies, pp. 407-418, Geological Society, Bath.

Viles, H.A. \& Goudie, A.S., 2004, 'Biofilms and case hardening on sandstones from Al-Quwayra, Jordan', Earth Surface Processes and Landforms 29, 1473-1485. doi:10.1002/esp.1134

Vincent, P.J., 1983, 'The morphology and morphometry of some arctic trittkarren', Zeitschrift für Geomorphologie 27, 205-222. 
Wagner, P.A., 1913, 'Negative spheroidal weathering and jointing in a granite of southern Rhodesia', Transactions of the Geological Society of South Africa 15, 155-163.

Walderhaug, O., 1998, 'Chemical weathering at rock art sites in western Norway: which mechanisms are active and how can they be retarded?', Journal of Archaeological Science 25, 789-800. doi:10.1006/jasc.1997.0224

Warke, P.A., McKinley, J. \& Smith, B.J., 2006, 'Variable weathering response in sandstone: factors controlling decay sequences', Earth Surface Processes and Landforms 31, 715-735. doi:10.1002/esp.1284

Wessels, D. \& Büdel, B., 1995, 'Epilithic and cryptoendolithic cyanobacteria of Clarens sandstone cliffs in the Golden Gate Highlands National Park, South Africa', Botanica Acta 108, 220-226.

Wessels, D. \& Schoeman, P., 1988, 'Mechanism and rate of weathering of Clarens sandstone by an endolithic lichen', South African Journal of Science 84, 274-277.

Wessels, D. \& Wessels, L., 1991, 'Erosion of biogenically weathered Clarens Sandstone by lichenophageous bagworm larvae (Lepidoptera: Psychidae)', Lichenologist 23 ,
283-291.

Wessels, D. \& Wessels, L., 1995, 'Biogenic weathering and microclimate of Clarens Sandstone in South Africa', Cryptogamic Botany 5, 288-298.

Wessels, D., Venter, D., Wessels, W. \& Wessels, L., 1995, 'Experimental strain analysis of Clarens Sandstone colonised by endolithic lichens', Koedoe 38, 35-47.

Wray, R.A.L., 1997, 'A global review on solutional weathering forms on quartz sandstone', Earth Science Reviews 42, 137-160. doi:10.1016/S0012 8252(96)00056-6

Young, A.R.M., 1987, 'Salt as an agent in the development of cavernous weathering', Geology 15, 962-966. doi:10.1130/0091-7613(1987)15<962:SAAAIT>2.0.CO;2

Young, R.W., Wray, R.A.L. \&. Young, A.R.M., 2009, Sandstone landforms, Cambridge University Press, Cambridge. 